\title{
U.S. DEPARTMENT OF THE INTERIOR U.S. GEOLOGICAL SURVEY
}

Geologic Map of the Piedmont in the Beltsville, Laurel, and Washington East Quadrangles, Montgomery, Prince Georges, Howard, and Anne Arundel Counties, Maryland and the District of Columbia

By

Avery Ala Drake, Jr. ${ }^{1}$

Open-File Report 98-520

This report is preliminary and has not been reviewed for conformity with U.S. Geological Survey editorial standards or with the North American Stratigraphic Code. Any use of trade, product, or firm names is for descriptive purposes only and does not imply endorsement by the U.S. Government.

${ }^{1}$ Reston, VA 


\title{
GEOLOGIC MAP OF THE PIEDMONT IN THE BELTSVILLE, LAUREL, AND WASHINGTON EAST QUADRANGLES, MONTGOMERY, PRINCE GEORGES, HOWARD, AND ANNE ARUNDEL COUNTIES, MARYLAND AND THE DISTRICT OF COLUMBIA
}

\author{
By
}

\section{Avery Ala Drake, Jr. \\ INTRODUCTION}

This part of the Maryland Piedmont is largely in Montgomery and Prince Georges Counties. Smaller areas are in Howard and Anne Arundel Counties, and the District of Columbia. Most of the area is suburban, and almost all outcrops are restricted to the Patuxent, Patapsco, Paint Branch, and other stream valleys. Crystalline rocks of the central Appalachian Piedmont are overlain by Coastal Plain deposits. Alluvium occurs along most streams. The geology of adjacent quadrangles to the west were mapped by Fleming and others (1994) and Drake (1998) and those to the north by Drake (in press a, b). The tectonics of the area were interpreted by Drake (1995).

\section{REGIONAL GEOLOGY}

This part of the Maryland Piedmont is on the east limb of the Baltimore structural culmination, a major internal basement massif in the central Appalachian orogen (Drake and others, 1988; Rankin and others, 1989, 1993). On this culmination are exposed Mesoproterozoic basement and its continental margin sequence cover in several antiformal windows through an obducted sequence of metamorphosed sedimentary and igneous rocks. These geologic relations were mapped in the Sykesville (Roen and Drake, in press) and Clarksville (Drake, in press a) quadrangles to the north. Here the obducted sequence consists of the Loch Raven-Laurel tectonic motif and the Baltimore thrust sheet.

\section{LOCH RAVEN-LAUREL TECTONIC MOTIF}

The Loch Raven-Laurel tectonic motif consists of a precursory sedimentary melange, the Laurel Formation $(\mathrm{El})$, and the Loch Raven thrust sheet, which are separated by the Burnt Mills thrust fault. The Loch Raven thrust sheet consists of the Northwest Branch Formation ( $\mathrm{EZn}$ ) and the Loch Raven Schist $(\mathrm{GZl})$. The Laurel precursory melange contains fragments of the overlying Loch Raven thrust sheet that calved from it during its emplacement during the sedimentation of the melange matrix (Fleming and others, 1994; Drake, 1998). The motif is a major tectonic unit in the Maryland Piedmont; the Loch Raven thrust sheet underlies about 400 square miles, and the Laurel Formation underlies about 80 square miles. 


\section{Loch Raven Thrust Sheet}

In Howard County, rocks of the Loch Raven thrust sheet were mapped as the oligoclase-mica schist facies of the Wissahickon Formation by Cloos and Broedel (1940) and were called Wissahickon Formation, eastern sequence, by Hopson (1964). Throughout the Maryland Piedmont these rocks were called the lower pelitic schist facies of the Wissahickon Formation (Southwick and Fisher, 1967).

\section{Northwest Branch Formation}

Meta-arenite and interbedded schist of the Northwest Branch Formation $(\mathrm{GZn})$ are well exposed along Paint Branch. The meta-arenite is fine grained and consists of abundant quartz and plagioclase and lesser biotite and muscovite. The rock has the composition of graywacke and subgraywacke. The meta-arenite forms thin, but continuous beds that average about 4 inches in thickness. Bedding can be determined easily at most places, particularly where meta-arenite and schist are closely interbedded. The meta-arenite lacks primary structures indicative of fluvial or shallow-water origin or features characteristic of turbidite sedimentation. Slump structures, however, are fairly common. This unit probably consists of marine silt and fine-grained sand that was deposited in a quiet, relatively deep basin.

Schist within the Northwest Branch Formation is identical to the overlying Loch Raven Schist $(\mathrm{GZI})$ into which it grades. The base of the unit is exposed nowhere because it overlies the Laurel Formation (Glo) on the Burnt Mills thrust fault.

\section{Loch Raven Schist}

The Loch Raven schist is poorly exposed and can be seen best in tributaries to the Patuxent River in the north part of the map area. Soil in areas underlain by the unit characteristically contains abundant flakes of coarse muscovite.

The schist contains scattered beds of meta-arenite identical to those in the underlying Northwest Branch Formation $(\mathrm{GZn})$. Elsewhere, bedding is obliterated. In this quadrangle, the schist is in amphibolite facies as it contains staurolite and oligoclase. At many places, it has been segregated by metamorphic differentiation. The schist consists mostly of quartz, muscovite, and biotite and much lesser amounts of plagioclase. Much of the rock is garnetiferous, and the more pelitic intervals contain staurolite porphyroblasts. In the map area, the schist is in amphibolite facies as it contains staurolite and oligoclase. Chemically, it is rich in alumina and alkalies, has a high Na-K ratio, and has a low silica content (Hopson, 1964).

In the northwestern corner of the map area, the Loch Raven Schist contains some interbedded quartzite (GZlq). The light-gray quartzite occurs in thin, mostly less than 8 inches thick, continuous beds. It contains no relict detrital sand grains. Chemical analyses of quartzite (Hopson, 1964) compare well with those of chert, or possibly, highly siliceous shale.

In the Clarksville quadrangle to the north (Drake, in press a), the Loch Raven Schist contains both mappable and unmappable layers of amphibolite as well as mappable blocks of serpentinized pyroxenite and amphibolite that have a spreading-center chemistry. Some of the amphibolite 
occurs as thin, discontinuous interbeds within the schist suggesting that it is metamorphosed mafic tuff. Amphibolite layers and blocks of serpentinite and amphibolite are common in the unit elsewhere in the Maryland Piedmont (Crowley, 1976).

\section{Tectonic Environment Of The Northwest Branch Formation And Loch Raven Schist}

As interpreted by Drake (1998), the Northwest Branch Formation and Loch Raven Schist were deposited in a quiet, relatively deep basin as shown by the chemistry of the schist and the lack of evidence of current activity in the arenitic rocks. That basin may have been a rift valley in a subaqueous volcanic ridge. Sediment deposited at such a site would consist largely of finegrained clastic material (silt, fine sand, and clay became meta-arenite and schist), some volcanic ash (became amphibolite), and minor amounts of silica (became chert and eventually quartzite) (Mitchell and Reading, 1986).

\section{Laurel Formation}

The Laurel Formation $(\mathrm{Gl})$, the precursory melange of the Loch Raven-Laurel tectonic motif, is well exposed along the Patuxent River, Paint Branch, Northwest Branch, and Sligo Creek. It is a medium-grained, quartzo-feldspathic granofels that is characterized by abundant quartz "eyes." It contains previously deformed and metamorphosed olistoliths of meta-arenite and schist derived from the Northwest Branch Formation and Loch Raven Schist, as well as a minor amount of amphibolite, presumably from the Loch Raven Schist. Individual slide units can be recognized in the Laurel, the lower part of an individual slide being olistolith poor and the top olistolith rich.

The upper part of the Laurel (Glo) contains more than 50 percent meta-arenite and schist olistoliths. Olistolith-rich rock can be seen best along Northwest Branch both northwest and southeast of the Capital Beltway and along Paint Branch south of Route 29. Much of this unit was mapped as oligoclase mica schist facies of the Wissahickon Formation by Cloos and Cooke (1953).

\section{BALTIMORE THRUST SHEET}

In this area, the Mount Washington Amphibolite (Om) constitutes the Baltimore thrust sheet and is the metamorphosed gabbro part of the Baltimore Complex (Higgins, 1977). The unit was interpreted to have been generated within a continental margin arc by Hanan and Sinha (1989) and Drake (in press b). The Mount Washington is covered almost entirely by Coastal Plain deposits in this area, but amphibolite can be seen along the Patuxent River at Laurel and near the north border of the map, and serpentinized olivine gabbro crops out along Sligo Creek. A chemical analysis of the olivine gabbro was given in Drake (1994). Along Sligo Creek, the gabbro was called "Sligo Creek Greenstone" by Gore (1981).

A geophysical study of the Baltimore Complex by Bromery (1968) found that these rocks constitute a slab, about 10,000 feet thick, both contacts of which dipped steeply west. Bromery (1968) interpreted this slab to be an intrusive sill, as had all previous workers. Crowley (1976), however, in a major contribution to Appalachian geology, found that the Mount Washington 
Amphibolite and Hollofield Ultramafite constitute a thrust sheet. The principal evidence for a fault is the truncation of map units both within the Baltimore Complex and within the surrounding rocks. In addition, there is no evidence of contact metamorphism in the metasedimentary rocks adjacent to the Baltimore Complex.

Bromery (1968) found that the contact of the Baltimore Complex with the Laurel Formation was marked by a strong positive aeromagnetic gradient. The trace of the Baltimore thrust fault in this area was placed on the extension of that gradient as shown on the aeromagnetic maps of Bromery and others (1963) and Fisher and others (1979).

\section{INTRUSIVE ROCKS}

The metasedimentary rocks have been intruded by small bodies of Guilford Granite (Dg) and related pegmatite $(\mathrm{Dp})$ as well as by a diabase dike (Jd).

\section{Guilford Granite}

A small body of Guilford Granite (Dg) has intruded the Laurel Formation on the west bank of Northwest Branch south of Franklin Knolls. Most of the Guilford Granite is monzogranite, but the unit has granodioritic phases (Drake, in press b). It is not deformed.

The Guilford magma apparently was quite fluid as outcrops in the area to the north have fairly abundant dikes, sheets, and blotches of related pegmatite (Drake, in press b). Many small bodies of pegmatite (Dp), which have intruded rocks of the Loch Raven-Laurel tectonic motif in this area, are interpreted to have stemmed from the Guilford magma.

The Guilford Granite and related pegmatites are clearly post-kinematic as they cut the regional foliation, as well as the Baltimore thrust fault to the north (Drake, in press b). There is no evidence of Devonian tectonism in this part of the Piedmont, so the Guilford probably formed by decompressional melting (Pitcher, 1982).

\section{Diabase}

One diabase dike (Jd) was mapped on the basis of float just south of Rocky Gorge Reservoir on the north border of the map. The rock is typical of other diabase dikes in the Piedmont (Hopson, 1964).

\section{STRUCTURAL GEOLOGY}

The stacked thrust sheets in this map area were obducted onto Laurentian basement and continental margin sequence in the area to the west on the Loch Raven thrust fault (Drake, 1995, 1998 , in press a, b; Roen and Drake, in press). The thrust stack, bottom to top, consists of the Loch Raven-Laurel tectonic motif and the Baltimore thrust sheet. Regionally, these rocks dip west because they are on the overturned east limb of the Baltimore culmination. 


\section{Structures in the Loch Raven-Laurel Tectonic Motif}

The Northwest Branch Formation and Loch Raven Schist were emplaced above the Laurel Formation on the Burnt Mills thrust fault first mapped in the Kensington quadrangle to the east (Drake, 1998). Evidence that the Laurel was being deposited during the emplacement of the thrust sheet consists of abundant olistoliths of previously metamorphosed and deformed metaarenite and schist. The Burnt Mills thrust fault, like the thrust faults in other tectonic motifs in the Virginia-Maryland Piedmont, is visualized to have formed near the base of a trench slope where it was stretched over the thrust toe that generated debris, which slumped to the base of the scarp (Drake, 1985). With continuing deformation, the debris was overrun by the thrust fault, forming the tectonic motif.

\section{Folds In The Loch Raven Thrust Sheet}

Two phases of macroscopic folds were mapped in rocks of the Loch Raven thrust sheet. The earliest phase folded bedding in the Loch Raven Schist along the northwestern border of the map. These folds trend east-northeast, are overturned to the south, and plunge west-southwest. The regional schistosity is axial surface to these folds. Folds having these characteristics were called Middle Patuxent folds by Drake (in press a).

Mesoscopic folds of bedding are isoclinal and in many outcrops have been sheared out and pass into transposition foliation. Most of these folds plunge west-southwest to south-southwest and plot on a great circle girdle, indicating that they have been refolded (fig. 1). Other axes have different attitudes, reflecting the complex structural geology of the area.

A second phase of macroscopic folds has the regional schistosity as its form surface. These folds are upright and plunge southwest. Folds having these characteristics were called Sligo Creek folds in the area to the west by Fleming and others (1994) and Drake (1998). Mesoscopic folds of schistosity plunge at different amounts to the southwest (fig. 1).

Two phases of macroscopic folds were mapped in rocks of the Laurel Formation. Both phases have foliation as their form surface. Folds of the most abundant, and probably oldest, phase are upright or overturned to the southeast, plunge either northeast or southwest, and fold the Burnt Mills thrust fault. These folds trace directly into Sligo Creek folds in areas to the west (Drake, 1998).

A second phase of folds was mapped north of Laurel. There the folds are overturned to the west and plunge north-northwest. Folds having these characteristics were called Columbia folds in the area to the north by Drake (1998). Interference between Sligo Creek and Columbia folds was not seen in the field, but Columbia folds are interpreted to be younger because they seem to be related to the rotation of regional structures from northeast to essentially north trends by sinistral strike-slip motion. 


\section{Structures In The Baltimore Thrust Sheet}

The Baltimore thrust fault placed the Mount Washington Amphibolite onto the Loch RavenLaurel tectonic motif. It is now overturned, the overturning being consistent with a steep westdipping contact of the Mount Washington Amphibolite as interpreted from geophysical data (Bromery, 1968).

The Baltimore thrust fault and the Mount Washington Amphibolite have been folded by Columbia phase folds in the area to the north (Drake, in press $b$ ). They are interpreted to be folded in the subsurface in this area (section A-A').

\section{ROCK CREEK SHEAR ZONE}

The Rock Creek shear zone is a dominant tectonic feature in Washington, D.C. and adjacent parts of Maryland (Fleming and others, 1992, 1994; Fleming and Drake, 1998; Drake, 1998). It is characterized by a composite fabric resulting from both early sinistral- and late dextral strikeslip motion. Drake (1998) mapped the shear zone up to the border of this map area near Cloverly, Maryland. There are no outcrops within the belt of Loch Raven Schist belt as far east as Burtonsville, Maryland. Farther east along the south-trending arm of Rocky Gorge Reservoir, however, outcrops of Loch Raven Schist contain abundant evidence of strike-slip shearing. There, meta-arenite beds within the schist are disrupted, and the rock is an autoclastic melange. Steep-plunging folds indicate sinistral-slip movement, whereas tails on boudinaged quartz veins indicate overprinting dextral-slip motion. These relations are characteristic of the Rock Creek shear zone; therefore that structure is interpreted to extend from Cloverly to the Rocky Gorge area. No evidence for shearing could be found farther north or in the adjacent Clarksville quadrangle (Drake, in press a).

\section{TECTONIC SYNTHESIS}

Drake (1995) showed that a stack of tectonic motifs was thrust onto the Laurentian continental margin early in the Taconic orogeny. The tectonic motifs, Laurentian basement, and continental margin sequence were then folded recumbently. In the south, rocks both east and west of the Mesoproterozoic core were intruded by numerous plutons that were interpreted to constitute a magmatic arc that had been built on the Laurentian margin (Drake and Fleming, 1994). This interpretation is supported by xenocrystic zircons from the intrusive rocks that yielded Mesoproterozoic ages (J.N. Aleinikoff, U.S. Geological Survey, written commun., 1996, 1997). The intrusive rocks range in age from $481 \mathrm{Ma}$ to $457 \mathrm{Ma}$, which constitutes early Taconic age as visualized by Drake and others (1989). That time agrees with the first appearance of flysch in the Martinsburg foreland basin in the central Appalachians (Drake and others, 1989).

The Baltimore thrust sheet appears to have been emplaced onto the Loch Raven-Laurel tectonic motif subsequent to the motif's obduction onto the Laurentian margin as units are cut out and the motif was nearly overrun to the north and east (Crowley, 1976). The Baltimore thrust sheet does not appear on the west limb of the culmination. Rocks of the Baltimore thrust sheet were generated within an ensialic basin (Hanan and Sinha, 1989; Drake, in press b). 
Following thrust sheets emplacment, they and the Laurentian basement and continental margin rocks were backfolded into a major east-verging massif. The emplacement of the thrust sheets and recumbent folding were interpreted to be the result of the east-dipping subduction of Laurentia beneath an oceanic sequence (Drake, 1995). This subduction, however, was aborted because of Archimedic buoyancy leading to subduction flip (Roeder, 1973) and east-verging retrocharriage. This deformation was completed by $368 \mathrm{Ma}$, the age of the Guilford Granite, which crosscuts the Taconic structures. 
Bowring, S.A., Grotzinger, J.P., Isochsen, C.E., Knoll, A.H., Pelechaty, S.M., and Kolosav, P., 1993, Calibrating rates of Early Cambrian evolution: Science, v. 261, p. 1293-1298.

Bromery, R.W., 1968, Geological interpretation of aeromagnetic and gravity surveys of the northeastern end of the Baltimore-Washington anticlinorium, Harford, Baltimore and part of Carroll County, Maryland: Unpublished Ph.D. dissertation, Johns Hopkins University, Baltimore, Maryland, 124 p.

Bromery, R.W., Gilbert, F.P., and others, 1963, Aeromagnetic map of the Beltsville quadrangle, Montgomery and Prince Georges County, Maryland: U.S. Geological Survey Geophysical Investigations Map GP-399, scale 1:24,000.

Cloos, Ernst, and Broedel, C.H., 1940, Geologic map of Howard County: Maryland Geological Survey, scale 1:62,500.

Cloos, Ernst, and Cooke, C.W., 1953, Geologic map of Montgomery County and the District of Columbia: Maryland Department of Geology, Mines, and Water Resources, scale 1:62,500.

Crowley, W.P., 1976, The geology of the crystalline rocks near Baltimore and its bearing on the evolution of the eastern Maryland Piedmont: Maryland Geological Survey Report of Investigations $27,40 \mathrm{p}$.

Drake, A.A., Jr., 1985, Tectonic implications of the Indian Run Formation--a newly recognized sedimentary melange in the northern Virginia Piedmont: U.S. Geological Survey Professional Paper 1324, $12 \mathrm{p}$.

1994, The Soldiers Delight Ultramafite in the Maryland Piedmont, in Drake, A.A., Jr. and

Pavlides, Louis, Stratigraphic Notes 1993: U.S. Geological Survey Bulletin 2076, p. A1-A14. 1995, Tectonic studies in the central Appalachian Piedmont--new findings: Geological Society of America Abstracts with Programs, v. 27, no. 1, p. 41. 1998, Geologic map of the Kensington quadrangle, Montgomery County, Maryland:

U.S. Geological Survey Geologic Quadrangle Map GQ-1774, scale 1:24,000. in press a, Geologic map of the Clarksville quadrangle, Howard, Montgomery, and Prince Georges Counties, Maryland: U.S. Geological Survey Open-File Report, scale 1:24,000. in press b, Geologic map of the Piedmont in the Savage and Relay quadrangles, Howard, Baltimore, and Anne Arundel Counties, Maryland: U.S. Geological Survey Open-File Report, scale $1: 24,000$.

Drake, A.A., Jr., and Fleming, A.H., 1994, The Dalecarlia Intrusive Suite and Clarendon Granite in the Piedmont of the Potomac Valley, in Stratigraphic notes 1991-92: U.S. Geological Survey Bulletin 2060, p. 25-33.

Drake, A.A., Jr., Hall, L.M., and Nelson, A.E., 1988, Basement and basement-cover relation map of the Appalachian orogen in the United States: U.S. Geological Survey Miscellaneous Investigations Map I-1655, scale 1:1,000,000.

Drake, A.A., Jr., Sinha, A.K., Laird, Jo, and Guy, R.E., 1989, The Taconic orogen, in Hatcher, R.D., Jr., Thomas, W.A., and Viele, G.W., eds., The Appalachian-Ouachita orogen in the United States: Boulder, Colorado, Geological Society of America, The Geology of North America, v. F-2, p. 101-177. 
Fisher, G.W., Higgins, M.W., and Zietz, Isidore, 1979, Geologic interpretation of aeromagnetic map of the crystalline rocks in the central Appalachians northern Virginia to New Jersey: Maryland Geological Survey Report of Investigations 32, $43 \mathrm{p}$.

Fleming, A.H., and Drake, A.A., Jr., 1998, Structure age, and tectonic setting of a multiply reactivated shear zone in the Piedmont in Washington, D.C., and vicinity: Southeastern Geology, v. 37, no. 3, p. 115-140.

Fleming, A.H., Drake, A.A., Jr., and McCartan, Lucy, 1992, The Rock Creek shear zone-a major tectonic feature in the central Appalachian Piedmont: Geological Society of America Abstracts with Programs, v. 24, no. 3, p. 21.

Fleming, A.H., Drake, A.A., Jr., and McCartan, Lucy, 1994, Geologic map of the Washington West quadrangle, District of Columbia, Montgomery County, Maryland, and Arlington County, Virginia: U.S. Geological Survey Geologic Quadrangle Map GQ-1748, scale $1: 24,000$

Gore, P.J.W., 1981, Stratigraphy and sedimentology of a metamorphosed diamictite: Wissahickon Group, southeastern Maryland Piedmont: unpublished MS Thesis, The George Washington University, Washington, D.C., 210 p.

Hanan, B.B., and Sinha, A.K., 1989, Petrology and tectonic affinity of the Baltimore mafic complex, Maryland, in Mittwede, S.K., and Stoddard, E.F., eds., Ultramafic rocks of the Appalachian Piedmont: Geological Society of America Special Paper 231, p. 1-18.

Higgins, M.W., 1977, The Baltimore Complex, Maryland and Pennsylvania, in Sohl, N.F., and Wright, W.B., Changes in stratigraphic nomenclature by the U.S. Geological Survey, 1976: U.S. Geological Survey Bulletin 1435-A, p. A127-A129.

Hopson, C.A., 1964, The crystalline rocks of Howard and Montgomery Counties, in The geology of Howard and Montgomery Counties: Baltimore, Maryland Geological Survey, p. 27-215.

Landing, Ed, 1994, Precambrian-Cambrian boundary global stratotype ratified and a new perspective of Cambrian time: Geology, v. 22, p. 179-182.

Mitchell, A.H.G., and Reading, H.G., 1986, Sedimentation and tectonics, in Reading H.G., ed., Sedimentary environments and facies, p. 439-476.

Pitcher, W.S., 1982, Granite type and tectonic environment, in Hsü, K.J., ed., Mountain Building Processes: New York, Academic Press, p. 19-40.

Plumb, K.A., 1991, New Precambrian time scale: Episodes, v. 14, no. 2, p. 139-140.

Rankin, D.W., Drake, A.A., Jr., Glover, L., III, Goldsmith, Richard, Hall, L.M., Murray, D.P., Ratcliffe, N.M., Read, J.F., Secor, D.T., Jr., and Stanley, R.S., 1989, Pre-orogenic terranes, in Hatcher, R.D., Jr., Thomas, W.A., and Viele, G.W., eds., The Appalachian orogen in the United States: Boulder, Colorado, Geological Society of America, The geology of North America, v. F-2, p. 7-100

Rankin, D.W., Drake, A.A., Jr., and Ratcliffe, N.M., 1993, Proterozoic North American (Laurentian) rocks of the Appalachian orogen, in Reed, J.C., Jr., Bickford, M.E., Houston, R.S., Link, P.K., Rankin, D.W., Sims, P.K., and Van Schmus, W.R., eds.: Precambrian: Conterminous U.S., Boulder, Colorado, Geological Society of America, The Geology of North America, v. C-2, p. 378-422.

Roeder, D.H., 1973, Subduction and orogeny: Journal of Geophysical Research, v. 78, no. 23, p. 5005-5024. 
Roen, J.N., and Drake, A.A., Jr., in press, Geologic map of the Sykesville Quadrangle, Howard, Carroll, and Baltimore Counties, Maryland: U.S. Geological Survey Open-File Report, scale $1: 24,000$.

Shaw, H.F., and Wasserburg, G.J., 1984, Isotopic constraints on the origin of Appalachian mafic complexes: American Journal of Science, v. 284, p. 319-349.

Sinha, A.K., Hannan, B.B., and Wayne, D.M., 1997, Igneous and metamorphic U-Pb ages from the Baltimore mafic complex, Maryland Piedmont, in Sinha, A.K., Whalen, J.B., and Hogan, J.P., eds., The nature of magmatism in the Appalachian orogen: Boulder, Colorado, Geological Society of America Memoir 191, p. 275-286.

Southwick, D.C., and Fisher, G.W., 1967, Revision of stratigraphic nomenclature of the Glenarm Series in Maryland: Maryland Geological Survey Report of Investigations, no. 6, 19 p. 


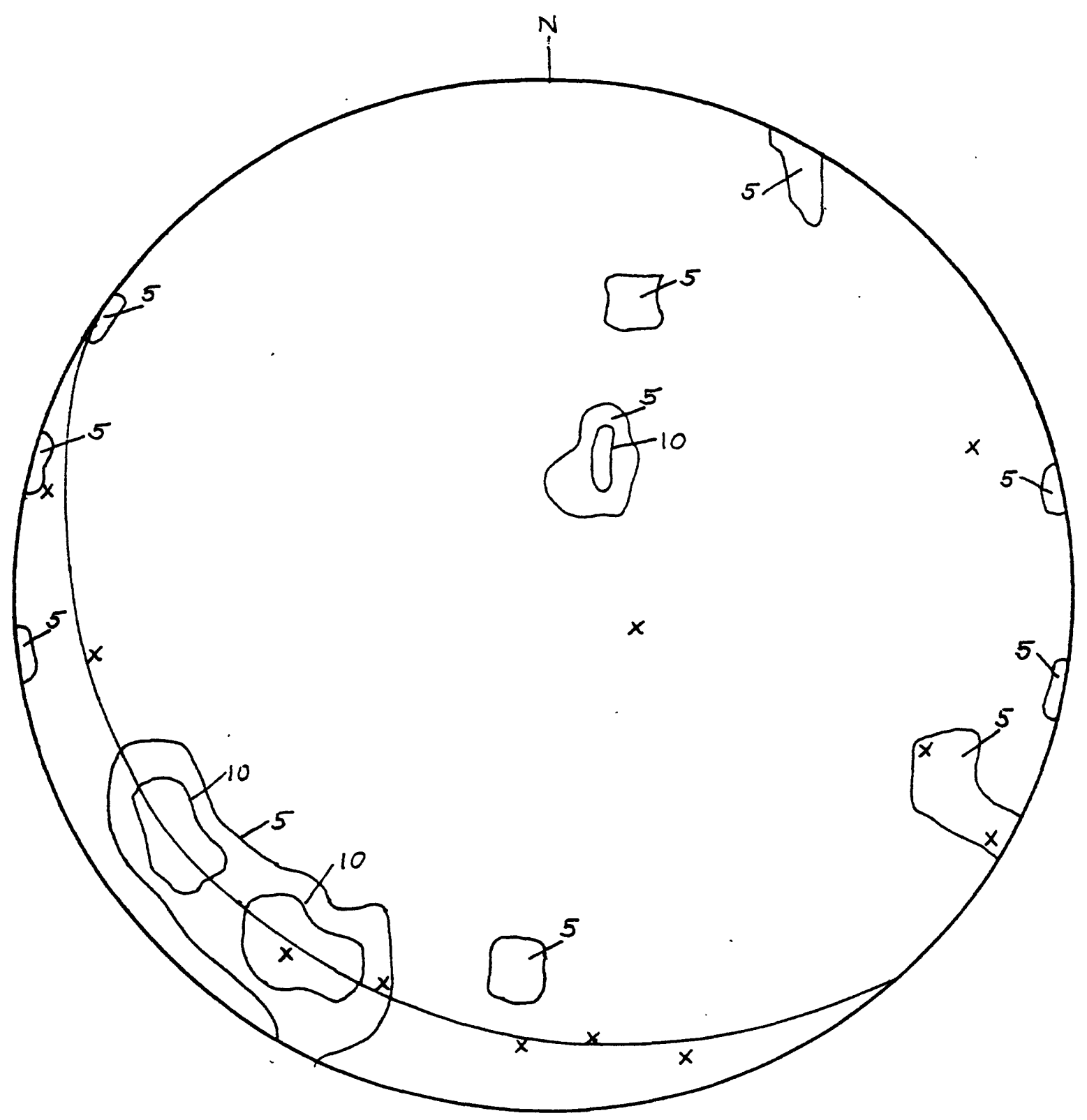

Figure 1. Equal area projection (lower hemisphere) of 20 axes of mesoscopic folds of bedding, $x$; and 11 axes of mesoscopic folds of schistosity, 0 , in rocks of the Loch Raven thrust sheet. Contours at 5 and 10 percent per 1 percent area. Dashed line is best fit girdle of axes to folds of bedding. 
CORRELATION OF MAP UNITS ${ }^{1}$

SURFICIAL DEPOSITS

Qal 3 Holocene $\}$ QUATERNARY

Unconformity

COASTAL PLAIN DEPOSITS

TK

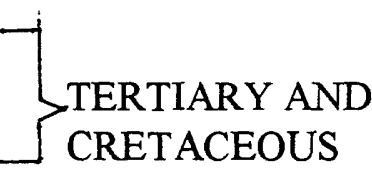

Unconformity

INTRUSIVE ROCKS

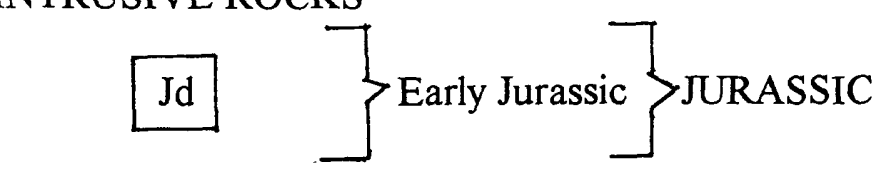

Intrusive Contacts

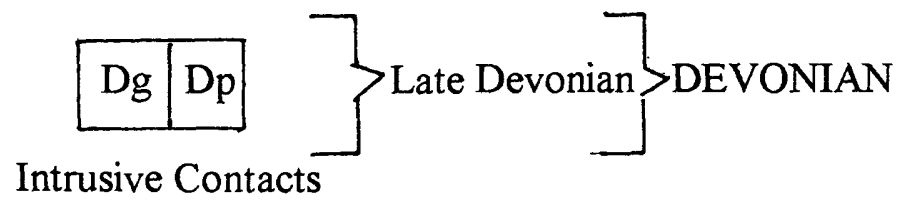

ARC ROCKS
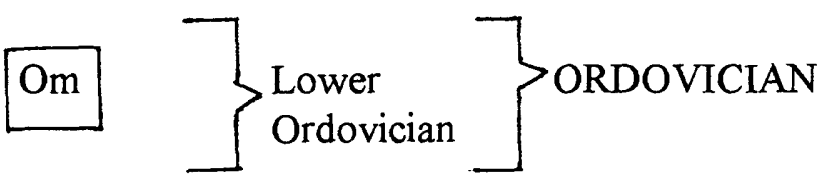

Baltimore Thrust Fault

LOCH RAVEN-LAUREL TECTONIC MOTIF

\begin{tabular}{|c|}
\hline Elo \\
\hline El \\
\hline
\end{tabular}

Burnt Mills Thrust Fault

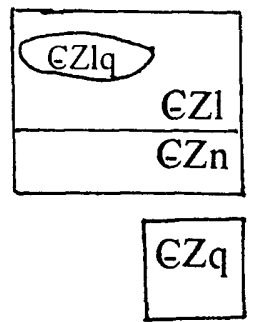

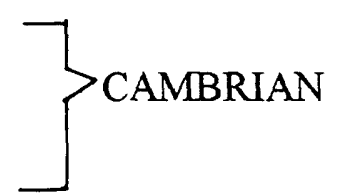

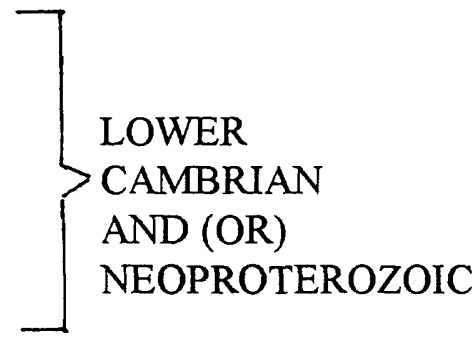




\section{DESCRIPTION OF MAP UNITS ${ }^{1}$}

\section{SURFICIAL DEPOSITS}

Qal Alluvium (Holocene)-Deposits of yellowish-brown sand, silt, gravel, and clay underlying sinuous floodplains along most streams. Fairly well bedded, poorly to moderately well-sorted, graded micaceous silt and sand, with gravel commonly filling scours at the base of upward-fining sequences. Locally contains quartz and crystalline rock pebbles, cobbles, and boulders

\section{COASTAL PLAIN DEPOSITS}

Tk Tertiary and Cretaceous rocks undifferentiated-Gravel, sand, silt, and clay. Unconformably overlies crystalline Piedmont rocks

\section{INTRUSIVE ROCKS}

Jd Diabase (Early Jurassic)-Medium- to dark-gray, fine-grained, largely equigranular pyroxene-plagioclase diabase

Dg Guilford Granite (Late Devonian) (Cloos and Broedel, 1940)-Light-gray, medium- to fine-grained, homogeneous monzogranite. About equal parts of microcline, plagioclase, and quartz constitute about 90 percent of the rock. Remainder consists of equal amounts of biotite and muscovite and minor amounts of apatite, garnet, clinozoisite, zircon, and magnetite. Contains dikes and thin stringers of pegmatite. The pegmatite has a nearly ideal granite composition, suggesting that it formed from residual Guilford magma. The Guilford has neither a tectonic foliation nor lineation. Zircons from the Guilford have a SHRIMP II age of $368 \pm 4$ Ma (J.N. Aleinikoff, U.S. Geological Survey, written commun., 1997). This age is the weighted average of 16 spot analyses on 16 grains. Two other grains had ages of about 1.2 and $1.4 \mathrm{Ga}$ showing that the Guilford magma had passed through Mesoproterozoic rocks

Dp Pegmatite (Late Devonian)-Light-gray to pinkish-gray pegmatite identical to that associated with Guilford Granite

\section{ARC ROCKS}

Om Mount Washington Amphibolite (Lower Ordovician) (Crowley, 1976)-Most of unit is fine- to medium-grained, dark-green to black amphibolite and minor pyroxene amphibolite. Rock in southwest corner of the map is serpentinized olivine gabbro. Shaw and Wasserburg (1984) published a model Nd-Sm isochron age of $490 \pm 20 \mathrm{Ma}$ for rocks equivalent to the Mount Washington, which they interpreted to be an igneous crystallization age, but noted that it might record a metamorphic event. More 
recently, Sinha and others (1997) obtained an U-Pb upper intercept age of $489 \pm 7 \mathrm{Ma}$ (MSWD=0.75) for zircons from the Mount Washington Amphibolite. The Mount Washington is here considered to be Early Ordovician in age

\section{LOCH RAVEN-LAUREL TECTONIC MOTIF}

Glo Laurel Formation (Cambrian) (Hopson, 1964)--Light- to medium-gray, medium- to

$\mathrm{Gl}$ coarse-grained, moderately to well-foliated sedimentary melange, consisting of a quartzofeldspathic matrix that contains quartz "eyes" and fragments of meta-arenite $(\diamond)$, schist $(\square)$, and amphibolite (\#). Typically spangled with very large muscovite porphyroblasts. Upper part of unit (Glo) contains more than 50 percent olistoliths of meta-arenite and schist. Thickness is indeterminate

EZlq

EZl Loch Raven Schist (Lower Cambrian and(or) Neoproterozoic) (Crowley, 1976)-Thin-bedded, medium-gray, lustrous, medium- to coarse-grained quartz-muscovitebiotite-plagioclase schist that at places contains garnet and(or) staurolite and(or) kyanite. Contains mappable quartzite ( $(Z \mathrm{Zlq})$, as well as some interbedded metaarenite similar to the underlying Northwest Branch Formation $(G Z m)$ into which it grades. Thickness is indeterminate

EZn Northwest Branch Formation (Lower Cambrian and (or) Neoproterozoic) (Drake, 1998)-Light-gray, medium-grained, well-bedded quartz-plagioclase-biotite metaarenite. Contains interbedded schist similar to the overlying Loch Raven Schist. Beds range from 0.5 inch to 4 feet in thickness. Has a good schistosity that is marked by biotite flakes. Thickness is indeterminate

EZq Quartz body (Lower Cambrian or Neoproterozoic)-Olistolith within the Laurel Formation

${ }^{1}$ The term "Neoproterozoic" follows the usage of Plumb (1991) and applies to rocks ranging in age from $1000 \mathrm{Ma}$ to $\sim 544 \mathrm{Ma}$ (base of Cambrian following Bowring and others, 1993; and Landing, 1994) 


\section{EXPLANATION OF MAP SYMBOLS}

- ? - Contact-Dotted where concealed, querried where location is uncertain

Distribution and concentration of structural symbols indicates degree of reliability

Faults-Dotted where concealed, querried where location is uncertain

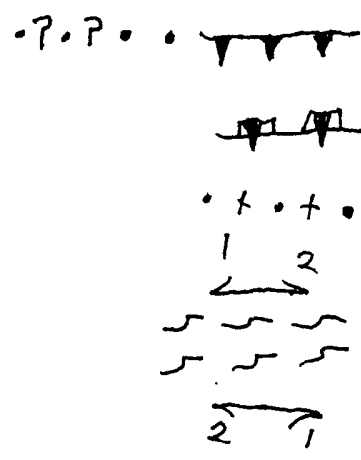

Thrust-Sawteeth on upper plate

Overturned thrust-Sawteeth in direction of dip; bar on tectonically higher plate

Trace of concealed thrust fault based on aeromagnetic data

Shear zone-Arrows indicate relative movement. 1, first movement; 2 , second movement

\section{FOLDS}

(Dotted where concealed)

Fold phases are designated from oldest to youngest: SS, Silver Spring; SL, Sligo; MP, Middle Patuxent; C, Columbia

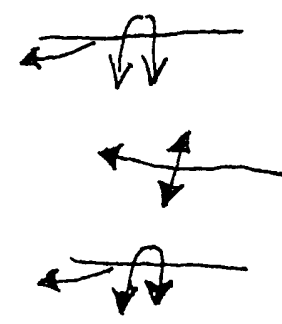

Overturned anticline showing trace of axial surface, direction of dip of limbs, and direction of plunge

Antiform-Showing crest line and direction of plunge

Overturned antiform-Showing trace of axial surface, direction of dip of limbs, and direction of plunge

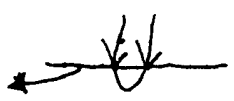

Overturned syncline-Showing trace of axial surface, direction of dip of limbs, and direction of plunge

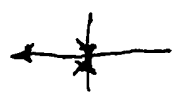

Synform-Showing trace of trough line and direction of plunge

Overturned synform-Showing trace of axial surface, direction of dip of limbs, and direction of plunge 


\section{MINOR FOLDS}

( $F$ indicates fold of foliation; $S$ indicates fold of schistosity)

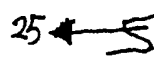

Minor asymmetric fold-Showing bearing and plunge of axis, and rotation sense viewed down plunge

$15 \longleftarrow$ Minor M-shaped fold-Showing bearing and plunge of axis

20

Minor fold-Showing bearing and plunge of axis

$\frac{1}{4}$

Minor fold showing rotation sense viewed in plunge

PLANAR FEATURES

(Symbols intersect at point of observations. May be combined with linear features)

Strike and dip of bedding

765

Inclined

$-75$

Overturned

$+$

Vertical

Strike and dip of crystallization foliation

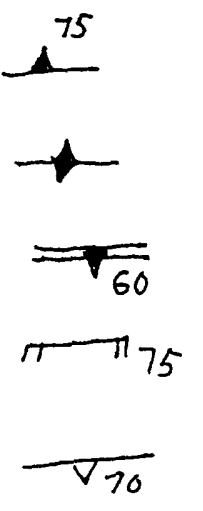

Inclined

Vertical

Mylonitic foliation

Shear band foliation

Transposition foliation

Schistosity

$\sqrt{25}$

Inclined

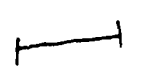

Vertical

$-75$

Crenulation schistosity 
$\begin{array}{ll}7180 & \text { Spaced schistosity } \\ 65 & \text { Strike and dip of joints }\end{array}$

LINEAR FEATURES

(May be combined with planar features)

$36 \longleftarrow \quad$ Mineral lineation

$45^{e} \leftarrow$ Elongation lineation

$30 \leftarrow \quad$ Intersection of bedding and schistosity or of two foliations

$45 \longleftarrow$ Crenulation

\section{OTHER FEATURES}

$7^{\text {bs }}$ Abandoned building stone quarry
Location of chemical analysis 10 in Drake (1994) 